\title{
Aplikasi “Ayamku” Untuk Pendataan Dan Pelaporan Hasil Penjualan Ayam Potong Berbasis Android
}

\author{
${ }^{1}$ Abdul Azis ${ }^{2}$ Riyanto ${ }^{3}$ Harni \\ ${ }^{123}$ Universitas Amikom Purwokerto, ${ }^{123}$ Fakultas Ilmu Komputer \\ ${ }^{123} \mathrm{Jl}$. Letd Jend Pol Sumarto \\ 19abdazis9@amikompurwokerto.ac.id, ${ }^{2}$ riyanto@amikompurwokerto.ac.id, \\ harni@gmail.com
}

\begin{abstract}
Abstrak: Pemotongan Ayam Potong Pak Agus merupakan tempat pemotongan ayam broiler yang sudah berdiri sejak tahun 2007 dan beralamat di Jl. Gunung Galunggung RT 04 RW 06 Pabuwaran, Purwokerto Utara. Selama ini dalam melakukan pendataan penjualan dan pembayaran masih dilakukan secara manual hanya menggunakan nota saja untuk orderan dari rumah makan, sedangkan untuk pembeli eceran tidak menggunakan nota. Beberapa kesulitan yang dihadapi adalah kesulitan dalam melakukan pengecekan stok ayam hanya mengira-ngira bobot ayam yang kiranya akan di order, dan juga rekap pembayaran yang masih ditulis dalam buku nota menjadikan banyaknya permasalahan dalam melakukan penjumlahan. Untuk membantu proses pendataan dan pelaporan hasil penjualan dibutuhkan suatu sistem, maka dibuatlah aplikasi pendataan dan pelaporan hasil penjualan ayam potong berbasis Android. Dalam pembuatan aplikasi ini menggunakan Android Studio dan menggunakan metode pengembangan sistem Waterfall. Dengan adanya sistem ini diharapkan dapat menunjang kinerja pada Pemotongan Pak Agus, memudahkan mengelola data pembelian dan penjualan.
\end{abstract}

Kata kunci: Android, Ayam, Android Studio, Waterfall

Abstract: Slaughtering the Chicken Pak Pak Agus is a place for cutting broiler chickens that have been established since 2007 and located at Jl. Gunung Galunggung RT 04 RW 06 Pabuwaran, Purwokerto Utara. During this time in conducting sales and payment data collection is still done manually using the only memorandum for orders from restaurants, while for retail buyers do not use memorandum. Some of the difficulties faced are the difficulties in checking the chicken stock, only estimating the weight of the chicken that would be ordered, and also the payment recapitulation which is still written in the memorandum makes many problems in doing addition. To help the process of data collection and reporting of sales results needed a system, an application for data collection and reporting of the sale of broiler chickens based on Android was made. In making this application using Android Studio and using the Waterfall system development method. With this system, it is expected to support the performance of Mr. Agus' Cutting, making it easier to manage the buying and selling data.

Keywords: Application, Chicken, Android Studio, Waterfall

\section{PENDAHULUAN}

Ayam broiler adalah salah satu ternak yang berkembang di masyarakat dan merupakan ayam pedaging unggul yang memiliki karakteristik khas dengan pertumbuhan cepat sebagai penghasil daging dan efisien dalam merubah pakan menjadi daging, maka ayam broiler banyak dipilih sebagai salah satu alternatif dalam memenuhi kebutuhan gizi [1] khususnya memenuhi 
kebutuhan daging bagi masyarakat luas [2]. Kebutuhan akan pemesanan ayam broiler di Indonesia sangat tinggi dikarenakan masyarakat inonesia sangat menyukai makanan denggan bahan baku ayam [3]. Kini semakin banyak olahan makanan berbahan utama daging ayam membuat permintaan pasar meningkat, ini sangat memberikan banyak peluang bagi masyarakat dalam membuka usaha ayam potong. Selama ini dalam melakukan pendataan [4] penjualan dan pembayaran masih dilakukan secara manual hanya menggunakan nota. Oleh karena itu, pemilik tidak mengetahui jumlah ayam yang dijual dan keuntungan [5] yang diperoleh setiap harinya. Untuk keuntungan yang diperoleh dalam satu bulan masih menggunakan perkiraan atau mengira-ngira saja, karena pemilik ayam potong tidak melakukan laporan baik itu laporan harian [6] atau mingguan bahkan bulanan [7]. Sedangkan, omset yang dicapai pun masih mengira-ngira saja. Setiap harinya Pemilik melakukan order Ayam broiler kepada pengepul ayam yang nantinya akan di jual kembali. Beberapa kesulitan yang dihadapi adalah kesulitan dalam melakukan pengecekan stok ayam hanya mengira-ngira bobot ayam yang kiranya akan di order, dan juga rekap pembayaran yang masih ditulis dalam buku nota menjadikan banyaknya kesalahan dalam melakukan penjumlahan. Dengan bantuan teknologi, diharapkan dapat memecah permasalahan yang terjadi di masyarakat aplikasi Android merupakan salah satu solusi yang dapat membantu pemilik Ayam untuk memproses hasil pendataan dan pelaporan hasil penjualan dan pembelian ayam secara Realtime [8], dapat di lakukan dimana saja dan kapan saja, Aplikasi Ayamku diharapkan dapat membantu dalam pendataan dan pelaporan hasil penjualan ayam potong tersebut serta bertujuan untuk mempermudah dalam pembuatan laporan hasil penjualan ayam potong. Dan dengan adanya layanan ini dapat menghemat biaya dan waktu, karena tidak perlu membeli buku nota dan menulis di kertas manual [9] lagi.

\section{METODE PENELITIAN}

\section{A. Metode Penelitian}

Jenis penelitian yang digunakan adalah penelitian dengan metode Extreme Programming (XP) [5] yaitu konsep pengembangan perangkat lunak yang menganut nilai-nilai utama simplicity, komunikasi, feedback, dan keberanian. Program Stunting dibangun menggunakan bahasa Pemrograman Website karena praktis dalam menggunakannya [6] dan terdapat fungsi-fungsi yang dinamis berupa template yang dapat dirubah dan menyesuaikan smatrphone [7]. Sementara itu, pengujian menggunakan uji unit testing dan uji Acceptance testing [8]. 


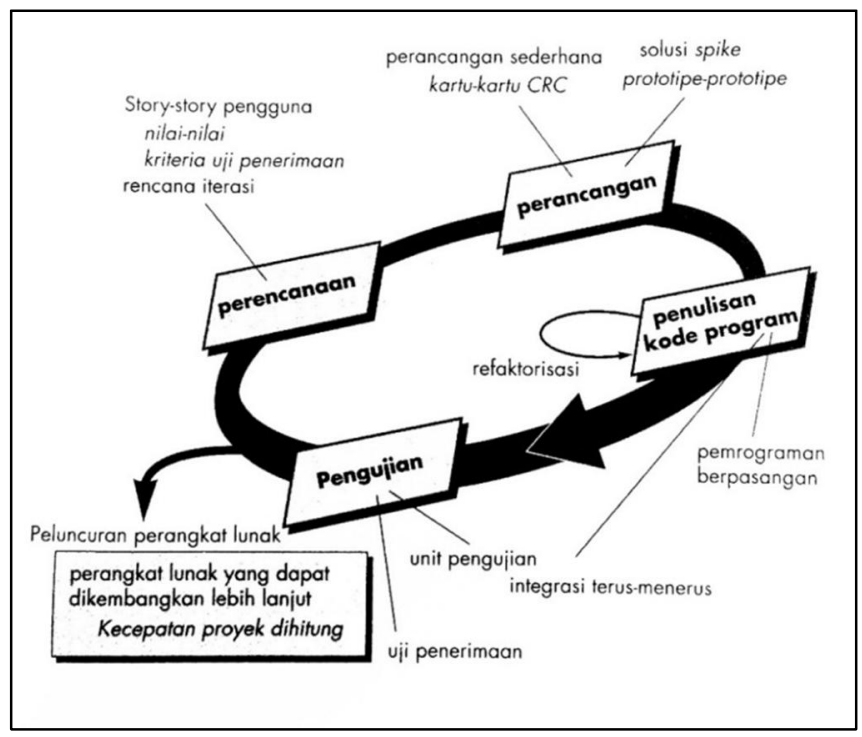

Gambar 1. Proses Metode Extreme Programming (XP)

\section{B. Perencanaan (Planning)}

Tahap Planning atau perencanaan dilakukan dengan mengumpulkan kebutuhan untuk memahami konteks pada aplikasi pengelolaan dan pelaporan konvergensi pencegahan stunting yang dibuat dan mendapatkan output aplikasi serta fitur dan fungsi utama pada aplikasi. Pada tahap ini peneliti mengumpulkan informasi dan data melalui observasi dan wawancara. Tahapan ini menciptakan sebuah alur sistem, kemudian pihak kecamatan memberikan nilai prioritas berdasarkan fitur atau fungsi keseluruhan.

C. Perancangan (Design)

Tahap Design dilakukan dengan pembuatan perancangan sederhana mengenai pengembangan aplikasi pengelolaan dan pelaporan konvergensi pencegahan stunting yang kemudian dilakukan pembuatan class diagram. Design dalam alur sistem dibuat dalam konteks berorientasi objek. Pembuatan Design menggunakan Spike Solution dimana pembuatan Design dibuat langsung ke tujuanya. Extreme Programming juga mendukung adanya refactoring dimana software sistem diubah sesuai dengan kebutuhan dan menyederhanakanya dan hasil dari kode tidak berubah. Pada tahap ini, penulis mendesain tampilan antar muka (user interface) aplikasi berdasarkan hasil dari tahapan sebelumnya.

\section{Penulisan Kode Program (Coding)}

Tahap coding pada XP diawali dengan membangun serangkaian unit test. Setelah itu pengembangan berfokus untuk mengimplementasikannya. Pengkodean aplikasi website menggunakan framework CodeIgniter dan menggunakan database MySQL [9]. Pengkodean ulang apabila dilakukan apabila hasil pengkodean ditemukan masalah atau bugs dan langsung dilakukan perbaikan sistem pada aplikasi. Pada tahapan coding terdapat kegiatan pair programming yaitu pengkodean secara berpasangan. Namun pada penelitian ini tidak dilakukan karena pada penelitian ini berfokus pada penelitian individu sehingga proses perancangan aplikasi dilakukan secara individu. Tahap ini adalah tahap pembuatan sistem dengan mengacu pada rencana dan perancangan yang telah dibuat.

\section{E. Pengujian (Testing)}

Tahap testing merupakan tahap akhir untuk mendapatkan hasil uji kelayaan sistem. Pengujian aplikasi bertujuan untuk mengetahui kesalahan-kesalahan yang mungkin terjadi jika aplikasi telah berada di tangan pengguna.

$\overline{\text { Abdul, et., al (Aplikasi “Ayamku” Untuk Pendataan dan Pelaporan Hasil Penjualan Ayam Potong Berbasis Android) }}$ 


\section{HASIL DAN PEMBAHASAN}

\subsection{Analisis Sistem}

Aplikasi AyamKu digunakan untuk memormudah pemilik ayam potong untuk mengetahui hasil pembelian, penjualan dan pelaporan hasil pembelian dan penjualan pada ayam potong secara Realtime dan tepat guna, karena dalam proses pendataan dan pelaporan ahasil penjualan ayam pemilik masih menggunakan kertas manual dimana hanya perkiraan saja yang dipakai untuk proses perhitungannya. Rekap pembayaran yang masih ditulis dalam buku nota menjadikan banyaknya permasalahan dalam melakukan penjumlahan.

\subsection{Alur Sistem}

Alur system yang dipakai dalam pembuatan aplikasi AyamkKu adalah menggunakan UML (Unified Modeling Language) pada gambar 2.

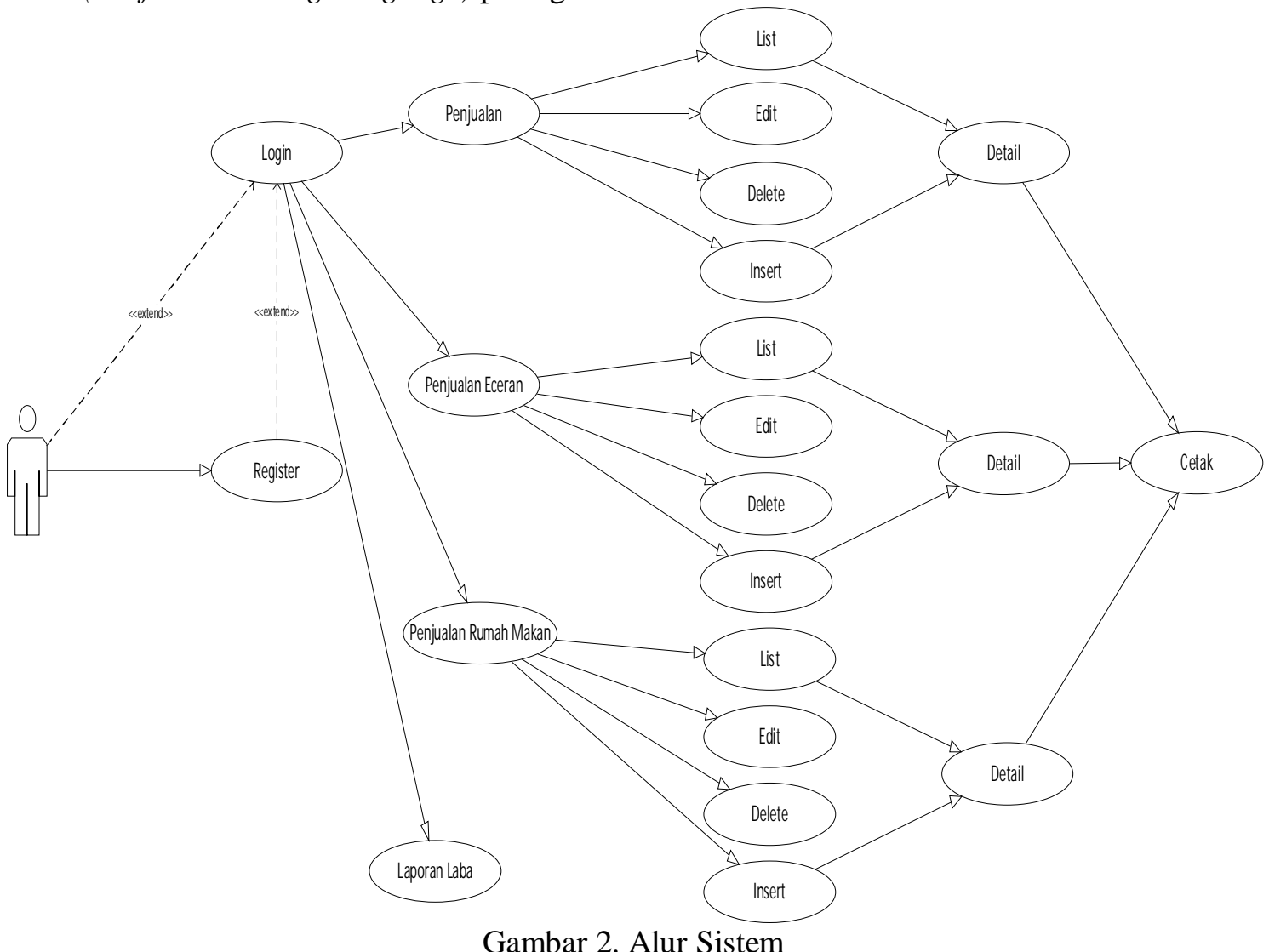

Gambar 2 menjelaskan tentang diagram use case pada Aplikasi pendataan dan pelaporan hasil penjualan ayam potong. Berikut adalah deskripsi pendefinisian diagram use case Aplikasi Aplikasi pendataan dan pelaporan hasil penjualan ayam potong sebagai berikut:

a. Aktor (Admin Aplikasi pendataan dan pelaporan hasil penjualan ayam potong)

Orang yang bertugas dan memiliki hak akses untuk melakukan seluruh operasi pengolahan data pembelian dan data penjualan.

b. Login

Merupakan proses untuk melakukan login.

c. Register atau Sign Up

Proses pendaftaran admin baru. 
d. Pembelian

Merupakan proses pembelian ayam dari pengepul ayam untuk nantinya dijual lagi.

e. Penjualan Eceran

Merupakan proses penjualan ayam secara satuan atau perekor.

f. Penjualan Rumah Makan

Merupakan proses penjualan ayam secara borongan kepada rumah makan tertentu.

g. Daftar atau List

Merupakan proses menampilkan daftar dari pembelian, penjualan eceran, atau penjualan rumah makan.

h. Edit

Merupakan proses mengubah data pembelian, penjualan eceran, atau penjualan rumah makan.

i. Delete atau hapus

Merupakan proses menghapus data pembelian, penjualan eceran, atau penjualan rumah makan.

j. Insert

Merupakan proses menambah data pembelian, penjualan eceran, atau penjualan rumah makan.

k. Detail

Merupakan proses menampilkan rincian data pembelian, penjualan eceran, atau penjualan rumah makan.

1. Cetak Struk

Merupakan proses mencetak struk pembelian, penjualan eceran, atau penjualan rumah makan dengan menggunakan thermal printer dengan sambungan bluetooth.

\subsection{Data Kondisi Penelitian}

\subsection{Aplikasi AyamKu}

\section{a. Use Case Diagram Aplikasi Ayamku}

Pada use case diagram Aplikasi pendataan dan pelaporan hasil penjualan ayam potong ini juga di gambarkan actor yang berhubungan dengan pengoperasian Aplikasi yaitu admin. Berikut use case diagram Aplikasi pendataan dan pelaporan hasil penjualan ayam potong pada gambar 3 


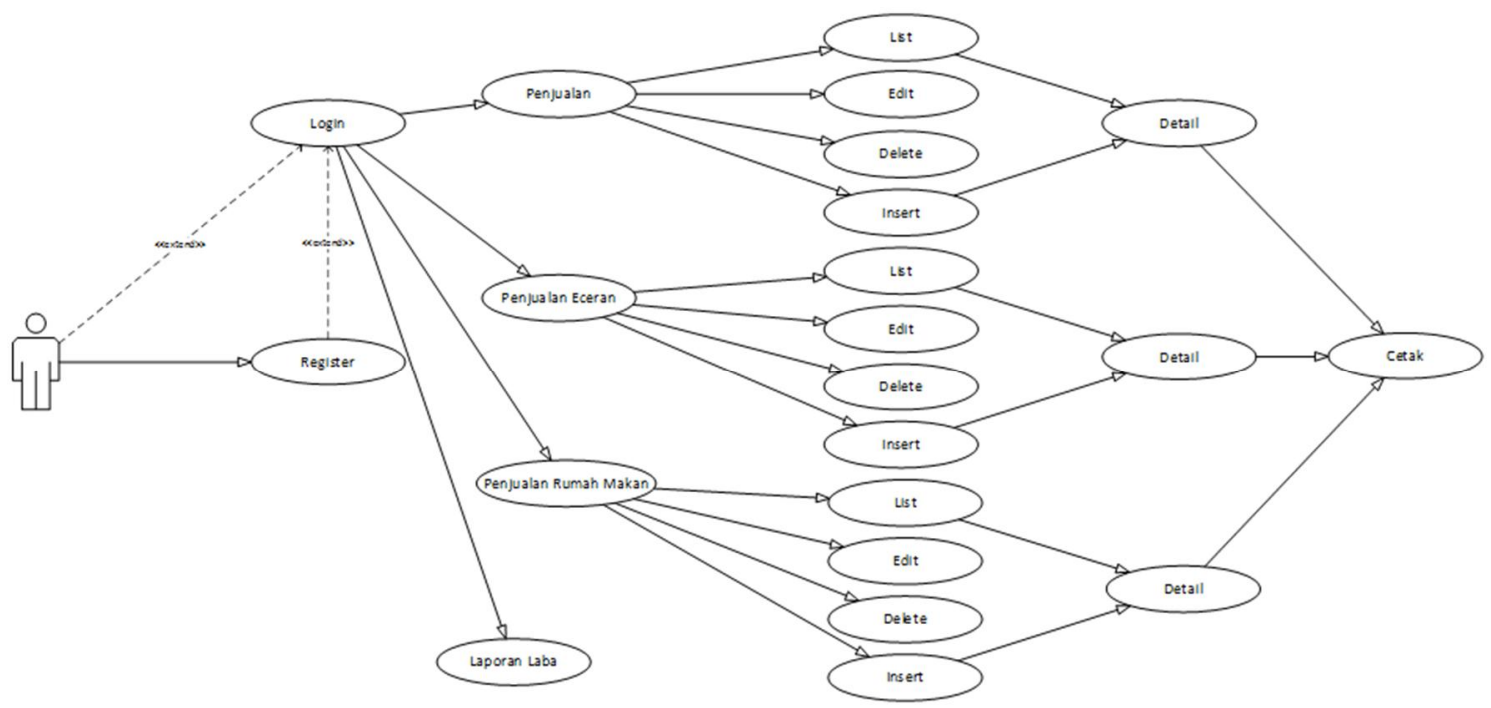

Gambar 3. Use Case Diagram Aplikasi

Gambar 3 menjelaskan tentang diagram use case pada Aplikasi pendataan dan pelaporan hasil penjualan ayam potong. Berikut adalah deskripsi pendefinisian diagram use case Aplikasi Aplikasi pendataan dan pelaporan hasil penjualan ayam potong sebagai berikut:

a) Aktor (Admin Aplikasi pendataan dan pelaporan hasil penjualan ayam potong) Orang yang bertugas dan memiliki hak akses untuk melakukan seluruh operasi pengolahan data pembelian dan data penjualan.

b) Login

Merupakan proses untuk melakukan login.

c) Register atau Sign Up

Merupakan proses pendaftaran admin baru.

d) Pembelian

Merupakan proses pembelian ayam dari pengepul ayam untuk nantinya dijual lagi.

e) Penjualan Eceran

Merupakan proses penjualan ayam secara satuan atau perekor.

f) Penjualan Rumah Makan

Merupakan proses penjualan ayam secara borongan kepada rumah makan tertentu.

g) Daftar atau List

Merupakan proses menampilkan daftar dari pembelian, penjualan eceran, atau penjualan rumah makan.

h) Edit

Merupakan proses mengubah data pembelian, penjualan eceran, atau penjualan rumah makan.

i) Delete atau hapus

Merupakan proses menghapus data pembelian, penjualan eceran, atau penjualan rumah makan.

j) Insert

Merupakan proses menambah data pembelian, penjualan eceran, atau penjualan rumah makan.

k) Detail

Merupakan proses menampilkan rincian data pembelian, penjualan eceran, atau penjualan rumah makan.

1) Cetak Struk

Abdul, et., al (Aplikasi “Ayamku” Untuk Pendataan dan Pelaporan Hasil Penjualan Ayam Potong Berbasis Android) 
Merupakan proses mencetak struk pembelian, penjualan eceran, atau penjualan rumah makan dengan menggunakan thermal printer dengan sambungan bluetooth.

\section{b. Sequence Diagram Penjualan Ayam}

Sequence Diagram Penjualan Ayam digunakan untuk melihat proses bisnis penjualan ayam eceran dan penjualan ayam borongan. Sequence Diagram Penjualan Ayam dilihat pada gambar 4 dibawah ini:
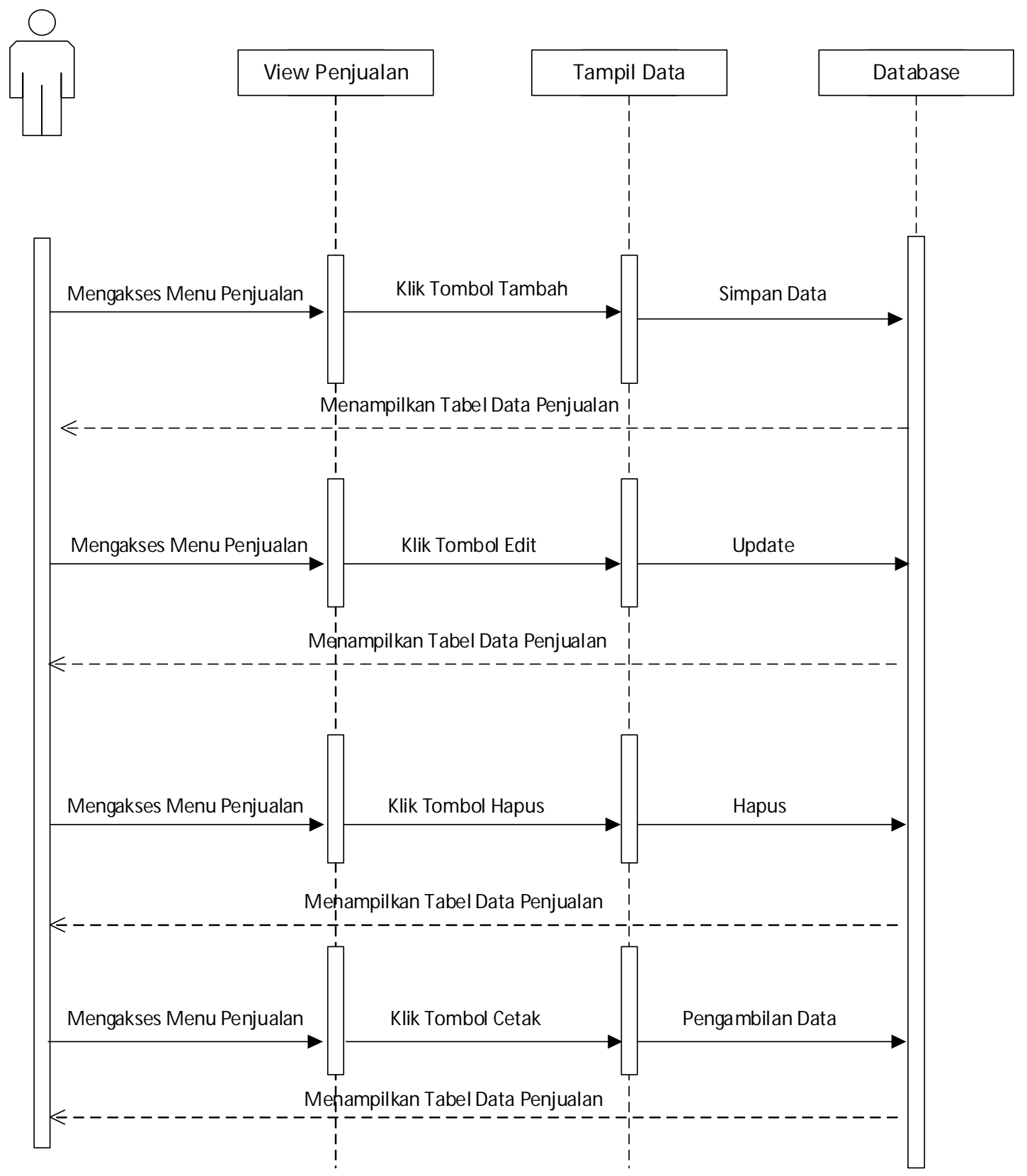

Gambar 4. Sequence Diagram Penjualan Ayam

$\overline{\text { Abdul, et., al (Aplikasi “Ayamku” Untuk Pendataan dan Pelaporan Hasil Penjualan Ayam Potong Berbasis Android) }}$ 
Pada sequence diagram diatas terdapat 1 admin dan 3 objek, yaitu: view penjualan, tampil data, database. Admin dapat menambahkan data penjualan, jika berhasil tersimpan maka akan tampil tabel data penjualan, admin dapat mengedit data penjualan dengan klik edit, jika berhasil maka akan menampilkan tabel data penjualan terbaru, admin dapat menghapus data penjualan dengan mengklik hapus, jika berhasil maka akan menampilkan tabel data penjualan terbaru. Dan admin juga bisa mencetak struk setiap detail data penjualan.

\section{c. Sequence Diagram Pembelian Ayam}

Sequence Diagram Pembelian Ayam digunakan untuk melihat proses bisnis pembelian ayam pada bakul. Sequence Diagram Pembelian Ayam dilihat pada gambar 5 dibawah ini:
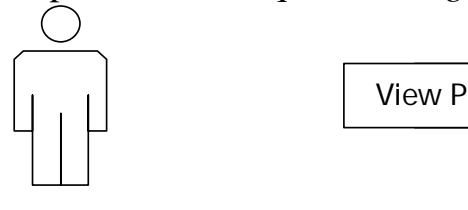

Pembelian
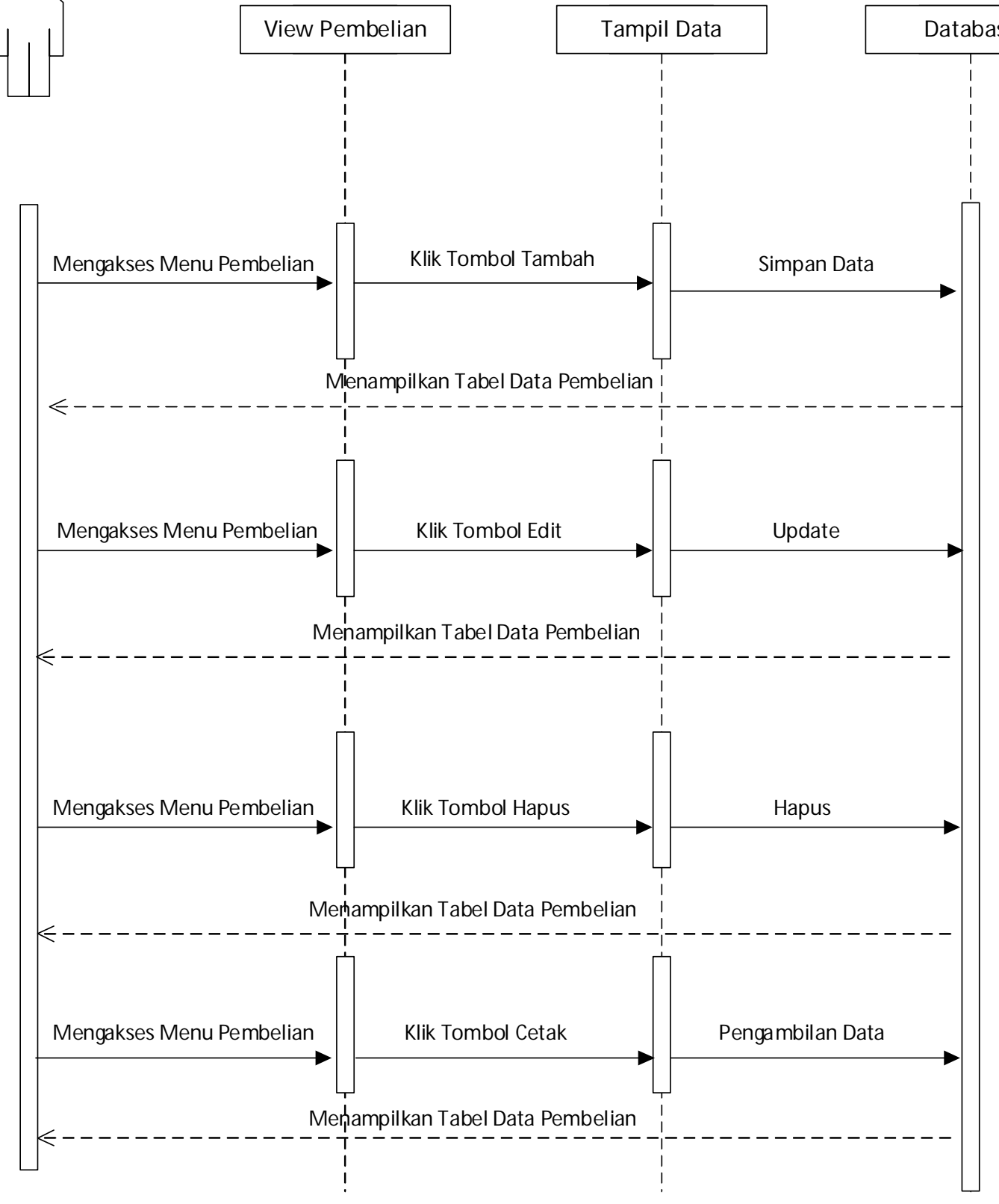

Gambar 5. Sequence Diagram Pembelian Ayam 


\section{d. Halaman Utama Aplikasi Ayamku}

Halaman utama digunakan untuk melihat seluruh transaksi yang terdapat dalam aplikasi AyamKu.

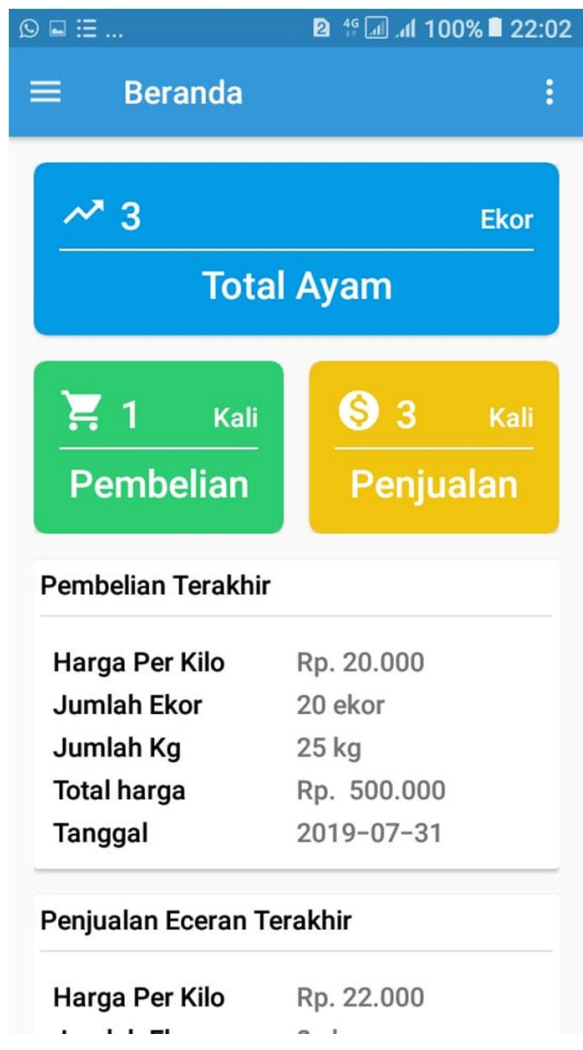

Gambar 6. Layout Beranda

Gambar 6 menjelaskan tentang layout beranda untuk admin. Layout ini berfungsi sebagai tampilan awal saat login ke dalam Aplikasi.

Pada sequence diagram diatas terdapat 1 admin dan 3 objek, yaitu: view pembelian, tampil data, database. Admin dapat menambahkan data pembelian, jika berhasil tersimpan maka akan tampil tabel data pembelian, admin dapat mengedit data pembelian dengan klik edit, jika berhasil maka akan menampilkan tabel data pembelian terbaru, admin dapat menghapus data pembelian dengan mengklik hapus, jika berhasil maka akan menampilkan tabel data pembelian terbaru. Dan admin juga bisa mencetak struk setiap detail data pembelian.

\section{e. Halaman laporan}

Halaman laporan digunakan untuk melihat hasil pembelian dan penjualan ayam potong. 


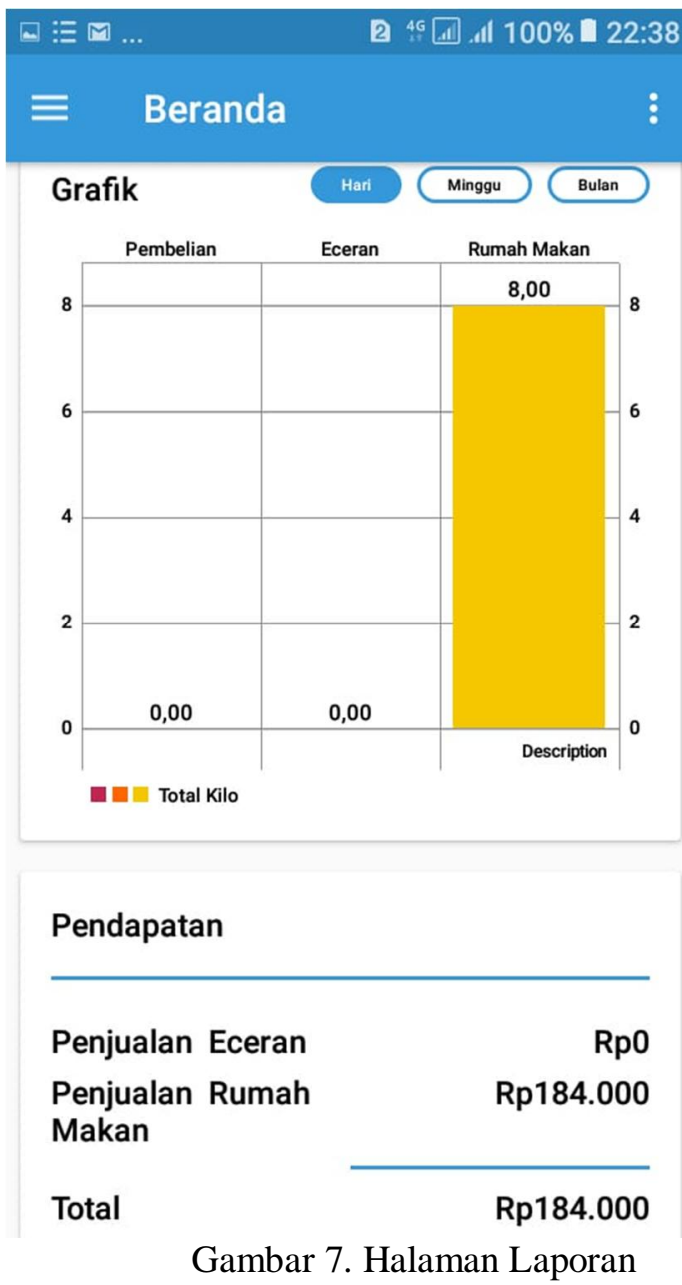

Gambar 7 menjelaskan tentang layout laporan laba. Layout ini berfungsi untuk menampilkan laporan laba perhari di pemotongan

\section{f. Arsitektur cetak penjualan printher termal}

Arsitektur sistem yang dibangun pada gambar 8 terdiri dari Aplikasi pendataan dan pelaporan hasil penjualan ayam potong yang berbasis android. Data disimpan pada database MySQL, transaksi penjualan akan dicetak dengan thermal printer melalui sambungan bluetooth. 


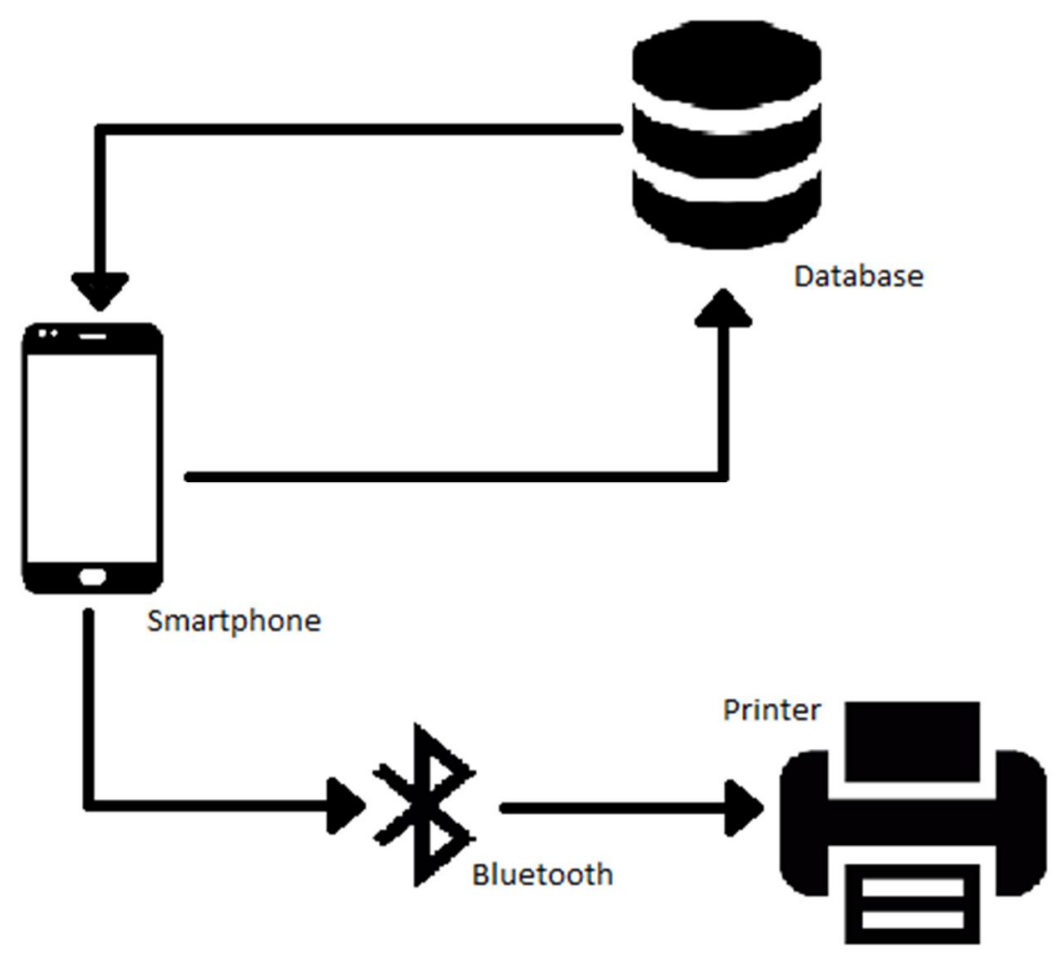

Gambar 8. Arsitektur Sistem

\section{g. Pengujian Validasi}

Hasil yang didapatkan dari pengujian akurasi sistem pakar ditunjukkan pada tabel 1 .

1. Hasil uji Validasi Penjualan

Tabel 1. Hasil Validasi

\begin{tabular}{|c|c|c|c|}
\hline $\begin{array}{c}\text { Fungsi } \\
\text { yang Diuji }\end{array}$ & Skenario Pengajuan & Hasil yang Diharapkan & $\begin{array}{c}\text { Hasil } \\
\text { Kenyataan }\end{array}$ \\
\hline \multirow{3}{*}{$\begin{array}{l}\text { Simpan } \\
\text { Data } \\
\text { Penjualan } \\
\text { Eceran }\end{array}$} & $\begin{array}{l}\text { Klik button Jual dan } \\
\text { input-an sudah diisi } \\
\text { dengan benar }\end{array}$ & $\begin{array}{l}\text { Data akan disimpan dan } \\
\text { data akan tampil di daftar } \\
\text { penjualan eceran }\end{array}$ & $\begin{array}{l}\text { Sesuai } \\
\text { Harapan }\end{array}$ \\
\hline & $\begin{array}{l}\text { Input-an belum diisi } \\
\text { semua }\end{array}$ & Akan muncul pesan error & $\begin{array}{l}\text { Sesuai } \\
\text { Harapan }\end{array}$ \\
\hline & $\begin{array}{l}\text { Input-an salah satu } \\
\text { atribut belum diisi }\end{array}$ & Akan muncul pesan error & $\begin{array}{l}\text { Sesuai } \\
\text { Harapan }\end{array}$ \\
\hline $\begin{array}{l}\text { Detail Data } \\
\text { Penjualan } \\
\text { Eceran }\end{array}$ & $\begin{array}{l}\text { Tekan dan tahan } \\
\text { beberapa saat pada salah } \\
\text { satu list, lalu pilih Detail }\end{array}$ & $\begin{array}{l}\text { Akan tampil detail } \\
\text { penjualan eceran sesuai } \\
\text { dengan data penjualan } \\
\text { eceran yang dipilih }\end{array}$ & $\begin{array}{l}\text { Sesuai } \\
\text { Harapan }\end{array}$ \\
\hline \multirow[t]{3}{*}{$\begin{array}{l}\text { Edit Data } \\
\text { Penjualan } \\
\text { Eceran }\end{array}$} & $\begin{array}{l}\text { Tekan dan tahan } \\
\text { beberapa saat pada salah } \\
\text { satu list, lalu pilih Edit }\end{array}$ & $\begin{array}{l}\text { Akan muncul tampilan } \\
\text { yang berisi data penjualan } \\
\text { eceran yang dipilih }\end{array}$ & $\begin{array}{l}\text { Sesuai } \\
\text { Harapan }\end{array}$ \\
\hline & Input-an sudah diisi & $\begin{array}{l}\text { Data di-update dan akan } \\
\text { tampil di daftar penjualan } \\
\text { eceran }\end{array}$ & $\begin{array}{l}\text { Sesuai } \\
\text { Harapan }\end{array}$ \\
\hline & Input-an & Akan muncul pesan error & Sesuai \\
\hline
\end{tabular}

$\overline{\text { Abdul, et., al (Aplikasi “Ayamku” Untuk Pendataan dan Pelaporan Hasil Penjualan Ayam Potong Berbasis Android) }}$ 


\begin{tabular}{lllll}
\hline & $\begin{array}{l}\text { semua } \\
\text { Input-an salah satu } \\
\text { atribut belum diisi }\end{array}$ & Akan muncul pesan error & $\begin{array}{l}\text { Harapan } \\
\text { Sesuai } \\
\text { Harapan }\end{array}$ \\
\hline $\begin{array}{l}\text { Hapus Data } \\
\begin{array}{l}\text { Penjualan } \\
\text { Eceran }\end{array}\end{array}$ & $\begin{array}{l}\text { Tekan dan tahan } \\
\text { beberapa saat pada } \\
\text { salah satu list, lalu pilih } \\
\text { Hapus }\end{array}$ & $\begin{array}{l}\text { Data penjualan eceran yang } \\
\text { terpilih dihapus }\end{array}$ & Sesuai Harapan \\
$\begin{array}{l}\text { Cetak Nota } \\
\begin{array}{l}\text { Penjualan } \\
\text { Eceran }\end{array}\end{array}$ & $\begin{array}{l}\text { Klik button Print pada } \\
\text { detail penjualan eceran }\end{array}$ & $\begin{array}{l}\text { Nota penjualan eceran akan } \\
\text { dicetak }\end{array}$ & Sesuai Harapan \\
\hline & $\begin{array}{l}\text { Bluetooth } \\
\text { dinyalakan }\end{array}$ & belum & $\begin{array}{l}\text { Akan muncul konfirmasi } \\
\text { untuk Sesuai Harapan } \\
\text { bluetooth }\end{array}$ & menyalakan \\
\hline & Printer tidak ditemukan & Akan muncul pesan error & Sesuai Harapan \\
\hline
\end{tabular}

2. Hasil Uji Validasi Pembelian

Hasil Uji Validasi dapat diliha pada Tabel 2 dibwah ini:

Tabel 2. Hasil Uji Validasi

\begin{tabular}{|c|c|c|c|}
\hline Fungsi yang Diuji & $\begin{array}{c}\text { Skenario } \\
\text { Pengajuan }\end{array}$ & $\begin{array}{c}\text { Hasil yang } \\
\text { Diharapkan }\end{array}$ & $\begin{array}{c}\text { Hasil } \\
\text { Kenyataan }\end{array}$ \\
\hline \multirow[t]{3}{*}{$\begin{array}{ll}\text { Simpan } & \text { Data } \\
\text { Pembelian } & \end{array}$} & $\begin{array}{l}\text { Klik button Beli } \\
\text { dan input-an sudah } \\
\text { diisi dengan benar }\end{array}$ & $\begin{array}{l}\text { Data akan disimpan dan } \\
\text { data akan tampil di } \\
\text { daftar pembelian }\end{array}$ & $\begin{array}{l}\text { Sesuai } \\
\text { Harapan }\end{array}$ \\
\hline & $\begin{array}{l}\text { Input-an belum } \\
\text { diisi semua }\end{array}$ & $\begin{array}{l}\text { Akan muncul pesan } \\
\text { error }\end{array}$ & $\begin{array}{l}\text { Sesuai } \\
\text { Harapan }\end{array}$ \\
\hline & $\begin{array}{l}\text { Input-an salah satu } \\
\text { atribut belum diisi }\end{array}$ & $\begin{array}{l}\text { Akan muncul pesan } \\
\text { error }\end{array}$ & $\begin{array}{l}\text { Sesuai } \\
\text { Harapan }\end{array}$ \\
\hline $\begin{array}{l}\text { Detail } \\
\text { Pembelian }\end{array}$ & $\begin{array}{l}\text { Tekan dan tahan } \\
\text { beberapa saat pada } \\
\text { salah satu list, lalu } \\
\text { pilih Detail }\end{array}$ & $\begin{array}{l}\text { Akan tampil detail } \\
\text { pembelian } \\
\text { dengan data pembelian } \\
\text { yang dipilih }\end{array}$ & $\begin{array}{l}\text { Sesuai } \\
\text { Harapan }\end{array}$ \\
\hline Edit Data Pembelian & $\begin{array}{l}\text { Tekan dan tahan } \\
\text { beberapa saat pada } \\
\text { salah satu list, lalu } \\
\text { pilih Edit }\end{array}$ & $\begin{array}{l}\text { Akan muncul tampilan } \\
\text { yang berisi data } \\
\text { pembelian yang dipilih }\end{array}$ & $\begin{array}{l}\text { Sesuai } \\
\text { Harapan }\end{array}$ \\
\hline
\end{tabular}

3. Hasil Uji Laporan

Hasil Uji Laporan dapat diliha pada Tabel 3 dibwah ini:

Tabel 3. Hasil Uji Laporan

\begin{tabular}{llll}
\hline $\begin{array}{c}\text { Fungsi yang } \\
\text { Diuji }\end{array}$ & \multicolumn{1}{c}{$\begin{array}{c}\text { Skenario } \\
\text { Pengajuan }\end{array}$} & Hasil yang Diharapkan & $\begin{array}{c}\text { Hasil } \\
\text { Kenyataan }\end{array}$ \\
\hline Tampil & Klik Laporan & Akan muncul laporan & Sesuai \\
Laporan Laba & Laba pada menu & $\begin{array}{l}\text { laba harian, mingguan, } \\
\text { dan bulanan }\end{array}$ & Harapan \\
& & &
\end{tabular}




\section{KESIMPULAN}

Aplikasi AyamKu diharapkan dapat mempermudah pemilik pemotongan untuk pendataan dan pelaporan hasil penjualan ayam potong dan mampu menampilkan hasil laporan penjualan dan Apliikasi ini menggunakan printer thermal yang digunakan untuk mencetak pembelian maupun penjualan ayam.

\section{SARAN}

Untuk sistem bisa di integrasikan dengan pengepul atau peternak di lapangan agar saling terintegrasi dengan yang laiinya.

\section{UCAPAN TERIMA KASIH}

Penulis mengucapkan terima kasih Kepada Universitas Amikom Purwokerto yang telah memberi dukungan.

\section{DAFTAR PUSTAKA}

1] Peraturan Menteri Kesehatan Republik Indonesia. 2014, Pedoman Gizi Seimbang.

[2] S. S. D. Damayati, Dwi Santy; Basri. 2017, Analisis Risiko Paparan Hidrogen Sulfida (H2S) pada Peternak Ayam Broiler di Kecamatan Maiwa Kabupaten Enrekang Tahun 2016, Hig. J. Kesehat. Lingkung.

[3] P. P. Ketaren. 2010, Kebutuhan Gizi Ternak Unggas di Indonesia, Wartazoa.

[4] D. P. Nugroho. 2013, Perancangan Pendataan Kependudukan Desa Sugihwaras, IJNS Indones. J. Netw. Secur. - ISSN 2302-5700 - 2354-6654.

[5] OJK, 2016. Pasar Modal, Otoritas Jasa Keuangan.

[6] J. HUTAHAEAN. 2017, Konsep Sistem Informasi.

[7] M. T. H. W. T. Amaliyah. 2016, Rancang Bangun Sistem Informasi Administrasi, JSIKA,

[8] A. Bewley, Z. Ge, L. Ott, F. Ramos, and B. Upcroft. 2016, Simple Online and Realtime Tracking, in Proceedings - International Conference on Image Processing, ICIP

[9] N. Norhikmah, A. R. Safitri, and L. A. Sholikhan. 2016, Penggunaan Qr Code Dalam Presensi Berbasis Android, Semnasteknomedia Online. 